\title{
Sobre criação dramatúrgica e encenação
}

\author{
José Eduardo Vendramini
}

O que sabe um artista a respeito da própria obra? No caso específico da dramaturgia, esse conhecimento é relevante para a concepção do espetáculo? E um conhecimento pedagogicamente transmissivel? Estas três perguntas têm-me inquietado com freqüência. Encenador, dramaturgo e professor universitário de Teatro, penso conhecer razoavelmente os três vértices desse triângulo e posso dizer de antemão e com bastante certeza: são todos igualmente pontiagudos e igualmente capazes de ferir os que se aproximam deles, sejam incautos principiantes ou experientes veteranos, porque em Arte ficamos todos vulneráveis.

No caminho que vai da intenção ao resultado, costumam ocorrer muitas surpresas, muitos acidentes de percurso. Mesmo que não ocorressem, o artista não tem algum tipo de controle para poder averiguar se o resultado final corresponde ou não à intenção inicial.

A criação de um texto teatral implica uma infinidade de procedimentos, alguns conscientes, outros não. Detectar os aspectos domináveis da atividade dramatúrgica, com o fim específico de averiguar se a criação artística é capacidade passivel de desenvolvimento, tem sido uma outra questão também inquietante para mim.

Existiriam métodos de organização do material imaginativo, que alguém pudesse, depois de vivenciá-los, transmitir aos interessados, em aulas ou por escrito? Muitas decisóes artísticas são provenientes da emoção, porém nem todas. Interessa-me investigar, além do seu peso, em que medida as motivaçōes do autor, absolutamente pessoais em sua origem, são passíveis de socialização, mais tarde, através da obra plasmada.

A criação de um texto teatral implica entre muitos outros - dois grandes procedimentos: imaginação e organizaçăo. O primeiro deles, pouco dominável (porém passível de desenvolvimento), confunde-se muitas vezes com o próprio 'fazer artístico', com o próprio 'ser artista'. O segundo, mais obediente à vontade, é o conjunto de atitudes que filtra, seleciona e estrutura o material fornecido pela imaginação.

Sem imaginação, o autor não tem material para trabalhar. Sem organização, por mais rico que seja, o material não se transformará em peça de teatro. Ou então, dará origem ao tipo de obra de que todos dizem: "A idéia é boa, mas a peça precisa ser reescrita" - frase terrível da

José Eduardo Vendramini é professor titular do Departamento de Artes Cênicas da ECA-USP.

Este texto é composto de excertos da minha Tese de Livre-Docência (VENDRAMINI, José Eduardo. Dramaturgia: criação e reflexão. São Paulo, ECA-USP, 1994, mimeo). 
qual qualquer autor quer escapar, porque, uma vez formalizadas, muitas idéias se recusam a ser reformuladas, sendo às vezes mais fácil criar uma peça nova do que refazer uma já pronta, porém com problemas.

\section{1}

A primeira questão formulada ("O que sabe um artista a respeito da própria obra?") tem implicaçóes com o domínio técnico. A respeito da própria obra, o artista que a criou pode até saber muito, mas com certeza não sabe tudo. É até capaz, evidentemente, de conhecer segredos inextrincáveis para leitores, encenadores e espectadores. Porém, pode não dominar alguns aspectos importantes, porque mantém com a mesma uma relação que só o tempo transformará em objetiva.

No caso da dramaturgia, o que o autor sabe a respeito da própria obra corresponde à compreensão profunda que todo encenador que se preza deveria ter de um texto antes de encenálo, mas não é a concepção do espetáculo propriamente dita. É, ainda, a pré-concepção, a visão do autor, aquilo que Copeau procurava e que Meyerhold procurava superar.

$\mathrm{O}$ que um dramaturgo sabe a respeito da própria peça, se esta é boa e aquele competente, deverá estar plasmado em forma de diálogos e rubricas, os quais, por sua vez, comportam enredo, personagens, tempo, espaço e, principalmente, ação dramática. Por mais culto que seja o dramaturgo, sua capacidade de analisar a própria peça não é garantia suficiente para torná-la teatral, encenável, de qualidade.

A consciência trabalha por camadas sucessivas de sedimentação. As sucessivas depuraçōes e triagens dariam, portanto, ao autor, uma consciência cada vez maior a respeito da própria obra. No entanto, sobra uma pergunta fatal: ao fazê-lo, ao obter a mencionada consciência crítica, estará o artista melhorando enquanto artista, ou se transformando definitivamente em crítico? Eé benéfica, em todos os sentidos, sem distinçōes, a consciência crítica? As obras mais relevantes, em termos artísticos, são aquelas criadas nos rompantes das grandes intuiçóes transgressoras, ou aquelas lapidadas à clara luz da mesa de trabalho do ourives?

Ao escrever uma peça de teatro, se o autor tem consciência de alguns postulados teóricos previamente organizados e sacramentados como sendo relevantes, poderá ele praticá-los melhor ainda quanto maior for essa consciência e menor for a participação inconsciente dos mesmos. Porém, a consciência crítica não substitui o fazer artístico, nem preenche lacunas deixadas por um talento claudicante. Por outro lado, não se pode esquecer que muitos dramaturgos ("conscientes" ou "ingênuos") já deram depoimentos sobre o caráter inoportuno - e até mesmo improdutivo - da consciência crítica durante o ato da criação de um texto teatral. Segundo essa linha de raciocínio, lembrar de técnicas de criação dramatúrgica, na hora mesma da escrita, seria tão inibidor quanto pensar nas funçóes do cerebelo durante uma relação sexual.

\section{2}

A segunda pergunta formulada ("No caso da dramaturgia, esse conhecimento é relevante para a consecução do espetáculo?"), é uma questão espinhosa, principalmente num século $\mathrm{XX}$ em que a liberdade do encenador foi reivindicada como princípio fundador de uma arte autônoma, a do fenômeno teatral, o espetáculo propriamente dito. Além disso, ela pode variar de autor para autor, de diretor para diretor.

Como encarar peças cifradas (penso em alguns exemplares do assim chamado Teatro do Absurdo), fragmentárias (como Woyzeck, de Büchner, ou praticamente todo o teatro de Qorpo Santo, por sua vez cifrado, fragmentário e surreal) ou, como na maior parte das vezes, ambíguas? Estaria a farsa isenta deste questionamento, por oferecer decodificação mais fácil? E quando a ambigüidade é produto tanto da estrutura quanto da açāo do tempo?

Radicalizando mais ainda: no caso de autores que já morreram, fica mais fácil ou mais 
difícil a arte da encenação? O controle excessivo que Jorge Andrade tentava exercer sobre as montagens de suas peças era benéfico ou prejudicial às mesmas? Era, no mínimo, teoricamente justificável? A fortuna crítica existente sobre Shakespeare, com todas as suas infinitas variantes, muitas delas contraditórias entre si, é imprescindível, acessória, contributiva ou um estorvo, quando do ato da encenaçáo?

A única resposta que posso oferecer com segurança a esta avalanche de questóes que, como um inábil aprendiz de feiticeiro, devo parecer estar chamando sobre mim mesmo, é que uma obra dramatúrgica é um sistema orgânico multiplicador de outros sistemas (encenaçóes diferenciadas), com os quais mantém relaçóes de interdependência, sob o risco de desfigurarse ou de se transformar apenas em pretexto, quando não compreendidos seus valores fundamentais ou quando mutilada em algum de seus principais elementos constitutivos, seja no nível do enredo, seja no nível da finalização verbal.

Penso que aquilo que um artista sabe a respeito da própria obra é relevante, no caso da dramaturgia, para a consecução do espetáculo, na medida em que estiver devidamente plasmado no texto. Caso não esteja, não há conhecimento no mundo - universitário ou não - capaz de insuflar vida artística a um objeto que não a tenha.

O texto dramático é a fonte e o articulador principal dos demais códigos do fenômeno teatral. Sistema orgânico multiplicador de outros sistemas (encenaçōes diferenciadas), com os quais mantém relaçōes de interdependência, a obra dramatúrgica pode ser comparada à partitura, em Música. Um ouvinte sensível consegue distinguir perfeitamente duas versões diferentes da mesma obra musical, produtos que são de diferentes orquestras e/ou maestros. Já em Teatro, o grau de variaçáo entre texto e espetáculo é maior do que entre partitura e execuçáo, em Música. Glenn Gould e Liberace não tocavam da mesma maneira a mesma obra, mas o conceito de partitura prevalece. Ulysses Cruz e Antunes Filho encenaram Macbeth com solu- çóes extremamente diferenciadas. Apesar da força extraordinária do original - ou do que sobrou dele - o conceito de encenação prevalece.

Diferenças à parte, é possível, porém apenas grosso modo, fazer o paralelismo entre Teatro e Música, e também dizer que o texto dramatúrgico está para o espetáculo assim como a partitura está para o concerto. Encenador e Maestro, portanto, seriam figuras homólogas. Neste sistema comparativo, evidentemente, o ator equivaleria ao instrumentista; o protagonista, ao virtuose, ao solista, ao spalla.

Porém, como a liberdade do encenador em relação ao texto é maior do que a do maestro em relação à partitura, eu proporia ainda a seguinte comparação: o encenador equivaleria ao maestro-arranjador, que, a partir de uma determinada frase melódica (tema musical / texto teatral) constrói o resto do arcabouço (harmonia / encenação) necessário ao fenômeno (concerto / espetáculo). Recentes recriaçōes da obra de Villa-Lobos, feitas por Egberto Gismonti e Issao Tomita, podem servir - purismos e gosto pessoal à parte - como exemplos esclarecedores.

$O$ que não se pode esquecer é que, dadas a melodia e a respectiva tonalidade, todo e qualquer arranjo, por mais criativo que seja, pressupóe uma harmonizaçáo compatível com as mesmas. A encenaçáo, do mesmo modo, pode (e deve) ser criativa, mas nunca aleatória, divergente em relaçáo ao texto (apesar dos grandes atrativos que a excentricidade traz ao merchandising), sob a pena de soar 'desafinada' ou ferir injustamente o original. Num concerto/espetáculo a quatro mãos, a partitura continua a mesma para os dois intérpretes, sejam eles dois pianistas ou um dramaturgo e um encenador.

O conhecimento dramatúrgico é o melhor alicerce para o futuro exercício da direção. Apesar de estarmos vivendo uma fase meio estranha (estou pensando no teatro em cartaz em 1994), em que alguns encenadores brasileiros em voga parecem estar mais interessados em roteiros de imagens, que lhes permitam - exatamente porque esgarçados - vôos de verdade assombrosos (porém, às vezes, discutíveis), a 
História do Teatro prova que um texto bem escrito não é obrigatoriamente uma camisa-deforça para a criatividade do diretor, mas sim a melhor chave, a melhor alavanca para a libertação do seu imaginário.

Conhecimentos de dramaturgia e de direção são complementares e úteis, reciprocamente. Primeiro, porque o autor escreve para ser encenado. (A edição de peças é uma finalidade de exceçáo, no caso do Teatro, e não a primeira, como na Literatura, que depende do texto impresso, para se concretizar como fenômeno.) Segundo, porque o diretor precisa saber destrinchar um texto, antes de encená-lo. Em síntese, o dramaturgo codifica, sabendo que essa codificação não é definitiva, é apenas parte de um processo maior. Em seguida, o diretor decodifica o texto, à procura do melhor critério de codificação do espetáculo, que, por sua vez, será mentalmente decodificado pelo público e pela crítica especializada.

Grandes encenaçōes já foram feitas a partir de autores que não estão mais vivos e/ou são parcos em rubricas. Prescindiram elas de boas e profundas exegeses? Seguramente, não. Ainda que o diretor alegasse ter agido de maneira intuitiva, e ainda que isso fosse verdade (do que, francamente, eu duvido), há nas atitudes artísticas um raciocínio embutido, subjacente, o qual muitas vezes equivale - e pode até mesmo ser superior - à análise puramente racional. (Faço esta reflexão a titulo ético e de reconhecimento do valor do trabalho de um bom encenador.)

\section{3}

A terceira pergunta formulada ("É um conhecimento pedagogicamente transmissível?") pressupōe resposta afirmativa. Obviedades à parte, todo conhecimento - por princípio - é transmissível e, no caso da Arte, rearticulável. Quantas encenaçóes já não foram provocadas - e serão, no futuro -, a partir de exegeses pertinentes e reveladoras de novos aspectos até então insuspeitados? ( $\AA$ memória, vêm-me As bacantes, de Eurípides, a partir de Freud, Reich e
Artaud; Sonho de uma noite de verão, de Shakespeare, a partir de Freud e Jan Kott, por exemplo.) Porém, se o receptor do conhecimento não for igualmente artista, haverá apenas a absorção de conteúdos, mas não a rearticulação artística, própria da invenção de um novo texto ou de uma encenação. A obra de arte em si, devo reconhecê-lo, é a melhor aula para artistas.

$\mathrm{Da}$ idéia geradora à redação final de uma peça, há um insuspeitado número de transformaçōes. Entre intenção e resultado nem sempre existe correspondência total. Partindo da força condutora da sua intuição, o dramaturgo organiza a matéria-prima (fornecida pela memória, vivência, observação, imaginação) em diálogos e rubricas, plasmando assim um texto que, por sua vez, se transforma novamente em matéria-prima, porém agora do trabalho do encenador, dos atores e da equipe de criação.

Nesse sentido, o autor decodifica e re-inventa a realidade e codifica a obra dramatúrgica. Posteriormente, diretor, atores e equipe de criação (cenógrafo, figurinista, iluminador, sonoplasta, aderecista, etc.) decodificam a mesma obra dramatúrgica e codificam a obra cênica. Finalmente, o público decodifica a obra cênica $\mathrm{e}$, através dela, e de formas as mais diferenciadas, conscientes ou inconscientes, a existência humana, ainda que a partir de um fragmento. Quanto mais universal for a temática, maior a probabilidade de decodificações. Insidiosamente, no entanto, o universal costuma mascararse, esconder-se atrás do particular. Portanto, nem sempre o historicismo é garantia de universalidade; pelo contrário, uma certa 'atemporalidade' costuma permear peças de interesse geral. A revitalizaçáo de mitos, de arquétipos, nesse sentido, é um recurso privilegiado, porque parte de experiências mais generalizantes.

Na dramaturgia, há um mínimo de informação que, se for reduzido excessivamente, pode até impedir o público de ter acesso ao prazer estético para o qual alguém teve a necessidade e a intenção de escrever aquela peça. Em contrapartida, se o nível de informação for ampliado em demasia, a obra corre o risco de ter 
seus significados não só codificados, como também decodificados no nascedouro, antecipando-se assim um momento do fenômeno teatral que acontece ao vivo, durante o espetáculo, $\mathrm{e}$ que depende da presença do público como coparticipante e não apenas como receptor passivo de significados decodificados. No caminho entre os dois pólos, e a cada nova peça, deve-se situar de forma pessoal cada dramaturgo.

Há um todo pretendido, que se concretiza em partes mínimas. $O$ efeito trágico, por exemplo, dos mais difíceis de se obter, exige esforço contínuo de controle, tanto dos grandes movimentos quanto dos detalhes. Se uma peça, ao ser encenada, produzir o impacto pretendido, será exatamente esse todo arduamente perseguido que poderá restar como experiência mais relevante para o público.

Apesar de lidar com a fantasia, a prática da dramaturgia não pode desprezar a coerência (interna, poética), resultado da organização, da catalisação do material produzido pelo imaginário para a instauração da criaçáo artística. Por outro lado, por mais coerente que tenha sido o processo de codificação da obra, a significaçáo é um espaço de controle parcial por parte do autor. Simples debates, após leituras dramáticas, comprovam que, ao se misturarem com o referencial de cada um dos presentes, as informaçōes e os estímulos contidos numa peça costumam dar origem a um insuspeitável número de ilações, nem sempre lógicas.

Diretamente proporcional à 'quantidade de Realismo' contida numa peça (o que não a impediria de dar o devido salto qualitativo rumo ao Transcendental), o controle das contradiçóes é um recurso que não inibe a imaginação. Pelo contrário, pode servir como sustentáculo e estímulo para a mesma.

Técnica e invenção não são - portanto contraditórias e/ou mutuamente excludentes: a criatividade pode, inclusive, sair beneficiada a partir de triagens prévias à escrita dramatúrgica. Feitas com o intuito de eliminar contradiçōes, essas mesmas triagens costumam induzir o aparecimento de detalhes enriquecedores, porém ainda submersos. Muitas vezes, em casos específicos, enquanto problemas de organização da estrutura da peça não se resolvem, a redação propriamente dita dos diálogos não deslancha. Concluo, daí, que o domínio técnico é libertador.

Nessa longa travessia, do universo nebuloso da intuição para o texto finalizado, o melhor guia ainda pode ser a tríade formada por personagens, ação dramática e enredo (independentemente do estilo pretendido). Não que os conteúdos não sejam bem-vindos. Pelo contrário. Porém, a arte do Teatro faz severas exigências quanto à intromissão dos mesmos. Os conteúdos devem estar embutidos nas ações das personagens e não à superfície do texto, sob a forma de (muitas vezes aborrecidas) preleções didatizantes (a nāo ser que assim o queira o dramaturgo). Uma peça que recuse o didatismo pode igualmente levar o leitor/espectador a fazer ilaçōes e a tirar conclusões relevantes a partir da leitura e/ou da encenação. O melhor veículo, portanto, para os conteúdos, é a ação dramática praticada pelas personagens e não a elocuçāo dos mesmos, pura e simples.

É quase impossível ao autor isentar-se emocionalmente em relação às personagens que cria. Assim, apesar da sempre desejada equalização das mesmas, em termos de simpatia/antipatia (para se deixar ao público um maior grau de participação e de arbitragem), é ilusório pensar que não haja encaminhamentos da afetividade do leitor/espectador latente na obra. Porém, se as simpatias e antipatias do autor em relação às personagens (muitas vezes indisfarçáveis e sempre produto da polarização de cada um em relação aos conteúdos em jogo) não forem bem equacionadas, a ação dramática propriamente dita não emergirá, ficando apenas no nível da discussão ética. E da filosofia falada, portanto. As vezes, da melhor qualidade, porém sempre com tendência ao teatro pouco teatral.

A ação dramática e a veiculação de conteúdos e informaçōes muitas vezes correm em direções opostas, sobretudo quando a personagem quer agir, mas o autor ainda precisa informar, para que o leitor/espectador possa compreender
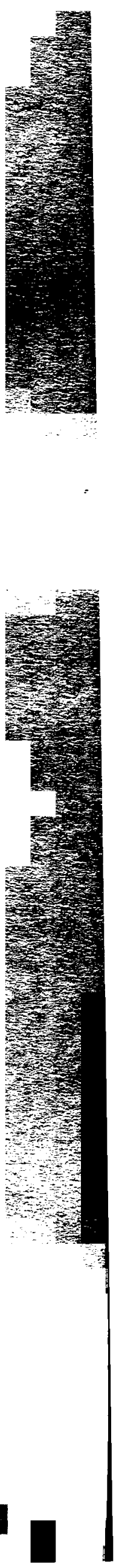
o significado daquela ação. O melhor teatro, em minha opinião, é aquele em que a ação dramática contém naturalmente as informaçōes necessárias.

A dosagem entre ação dramática e informaçáo constitui-se em problema crucial. Se o autor não equacionar de forma conveniente os conteúdos, a peça correrá o risco de não ter o que comunicar ao leitor/espectador. Porém, se o dramaturgo explicitar em excesso os mesmos e os desvincular da ação dramática, haverá o perigo do barateamento e do empobrecimento da informação artística. Penso que a saída para o problema estaria na qualidade do registro da ação dramática. Assim, quanto mais sintética e viva, tão melhor o resultado final, ao nível da escritura.

Como se fosse a ponta de um iceberg, o que aparece escrito é - portanto - apenas parte de um grande sistema, sua suma. O autor lida sempre com o binômio fatos / conteridos subjacentes aos fatos, à procura, consciente ou inconscientemente, dos arquétipos e da revelação transcendente. $\mathrm{O}$ melhor sistema simbólico é aquele que vem plasmado em realismo, embutido nele com naturalidade, confundindo-se com ele numa entidade única.

Dentro do Realismo, quanto menos interrupçōes temporais, menor liberdade terá o autor no que tange às entradas e saídas de personagens. Pelo contrário, se houver variaçōes temporais, acompanhadas também de variações espaciais, terá ele maiores chances de combinatórias, uma vez que o enredo será focado nas pontas dos icebergs da ação dramática e não nas suas bases (como é o caso da ação contínua). Nesse sentido, e apesar dos seus detratores, o Realismo é tão ou mais difícil do que as formas mais abertas, pois nele é raro conseguir-se as sínteses necessárias sem ferir os princípios da verossimilhança.

Não gostaria que essas observações soassem como apologia do Realismo. O primado da ação dramática independe de estilos. No caso do enredo realista contínuo (atos sem interrupçōes, com cenas em seqüência temporal cronológica, sem recurso ao jogo de luzes para indi- car mudança de espaço ou passagem de tempo), este tipo de estrutura é muito trabalhosa e exige minucioso estudo das motivaçōes, síntese poderosa ao nível das açōes e eliminação das contradiçóes, às vezes até com o sacrifício de detalhes armazenados com carinho. $\mathrm{O}$ plano da obra, portanto, impóe-se desde o início como condição sine qua non para sua execução.

O planejamento de uma peça não pode ser encarado apenas como 'domínio técnico', mas sim como uma das etapas de sua criaçáo, como a articulação dos dados fornecidos pela intuição (amálgama de memória, vivência, observação, imaginação). O plano da obra, prévio ao início da escritura, é benéfico ao todo e não disputa seu lugar com a intuição. Pelo contrário, instrumenta-a e dá-lhe a melhor e mais adequada finalização, sempre à procura desta pedra preciosa que se chama emoção reveladora, material nobre para dramaturgos e atores (pelo menos numa determinada intencionalidade).

Com certeza, todo autor de teatro coloca em cada peça que escreve, com maior ou menor intensidade, seus valores emocionais e pessoais profundos. No entanto, e por melhores que esses valores possam ser, e ainda que o escritor esteja bem intencionado, o que importa saber é se esses mesmos valores realmente se articulam em forma de um sistema dramatúrgico orgânico, ou seja, a peça finalizada e passível de encenação. Assim, o binômio intuição / técnica é fundamental para o autor de teatro, não podendo ele prescindir de nenhum destes dois elementos constitutivos de seu labor.

O domínio do diálogo pressupõe também o do subtexto. Quanto maior a tensão entre os dois, maior a quantidade e a riqueza dos significados. Nesse sentido, o dramaturgo provê o encenador $e o$ ator com material de trabalho, que se almeja sempre competente. $O$ texto tem a capacidade de prever (ou pelo menos de conter, em latência) os códigos do espetáculo. O dramaturgo escreve diálogos e rubricas, dando ênfase aos primeiros. Porém, o melhor - para o encenador - muitas vezes está mais nas rubricas e nas 'emendas' entre as cenas, mais próximas 
do palco, do que nos diálogos. Apresenta-se, assim, fatalmente, a questão hierárquica: a encenação é subsidiária da dramaturgia, ou é esta que deve se submeter às leis do espetáculo?

Concebo, sem qualquer tentativa de conciliação facilitadora, a dramaturgia e a encenaçăo como sistemas interdependentes e mutuamente fecundantes. É pouco provável uma boa encenação nascer de um texto ruim. Em contrapartida, o dramaturgo que não se interessar pelas rígidas leis que regulam a cena, corre o risco de escrever palauras e não teatro. Não estou com isso pretendendo o fim da elaboraçáo verbal. Penso, no entanto, que aquela elaboração verbal que o Teatro pede é especifica. Não é melhor nem pior do que a da Literatura. É, apenas, especificamente teatral, feita para ser representada.

Não há evolução dramatúrgica sem evolução pessoal do dramaturgo. Pessoas patinando na mesmice terão poucas chances de evoluir, tanto ao nível particular quanto artístico. Poucos - como Tchékhov - terão o incomparável e inatingível talento para obter grandes iluminaçōes cósmicas a partir da observação de penumbras individuais e sociais. Portanto, evolução do dramaturgo e evolução pessoal - penso - são também interdependentes.

Sei que pode parecer pretensão e até mesmo pedanteria, mas, na verdade, a pergunta obsedante que me atormenta é aquela - hamletiana - que diz respeito ao significado da vida (da minha e dos outros) e posso dizer com certeza que, sempre que consigo (ou, pelo menos, penso tê-lo conseguido) plasmá-la em forma de personagens, ações dramáticas, situações teatrais, diálogos e enredos socialmente reconhecíveis, encenáveis e interessantes para o público, sinto um prazer intenso.

O palco é a prova dos nove da dramaturgia.

A prática teatral é a prova dos nove da teoria teatral.

Quando os dois lados dos dois binômios se confundem, o teatro deve estar vivo.

Se a leitura destas páginas, que passo a considerar como uma aula de dramaturgia por escrito, proporcionar algum crescimento ao leitor, pelo menos terei conseguido provar uma das hipóteses das quais parti no início, ou seja, a de que a prática artistica pressupóe um conhecimento transmissivel. 